\title{
PENGARUH DISIPLIN MOTIVASI DAN PELATIHAN TERHADAP KINERJA KARYAWAN PASDA PT. BANK RAKYAT INDONESIA (PERSERO) KALIANDA
}

\author{
Iskandar Ali Alam \\ Fakultas Ekonomi Universitas Bandar Lampung \\ Jl. Z.A Pagar Alam No. 26 Labuhan Ratu Bandar Lampung 35142 \\ Telp. 0721-701979 Fax 0721701463 \\ Tata Putri Ari Nurhalimah \\ Fakultas Ekonomi dan Bisnis Universitas Bandar Lampung J1. Z.A \\ Pagar Alam No. 26 Labuhan Ratu Bandar Lampung 35142 Telp. \\ 0721-701979 Fax 0721701463
}

\begin{abstract}
ABSTRAK
Masalah sumber daya manusia masih menjadi sorotan utama bagi perusahaan untuk tetap dapat bertahan di era globalisasi. Sumber daya manusia mempunyai peran utama dalam setiap kegiatan perusahaan. Semua tindakan yang diambil dalam setiap kegiatan diprakarsai dan ditentukan oleh manusia yang menjadi anggota perusahaan. Oleh sebab itu keberhasilan suatu organisasi dipengaruhi oleh kinerja individu pegawainya, suatu organisasi akan berupaya untuk meningkatkan kinerja pegawainya dengan harapan dan tujuan perusaan dapat tercapai dengan efektif dan efisien.

Dalam penelitian ini menggunakan program SPSS for Windows versi 17.0. Hasil penelitian ini menunjukkan bahwa hasil regresi linier berganda $Y=5,842+0,603 X_{1}+0,886 X_{2}+0,503 X_{3}$ maka dapat disimpulkan bahwa sebagian besar responden memilih faktor Motivasi $\left(\mathrm{X}_{2}\right)$ yang paling besar mempengaruhi Kinerja Karyawan dengan koefisien (0,886\%). Hasil analisis uji $\mathrm{F}$, nilai $\mathrm{F}_{\text {hitung }}$ sebesar 39,323 dengan signifikan 0,000 lebih kecil dari 0,05 menunjukan bahwa secara bersama-sama variabel Motivasi, dan Pelatihan kerja mempunyai pengaruh positif dan signifikan terhadap Kinerja Karyawan. Hasil analisis uji $\mathrm{T}$, nilai $\mathrm{t}_{\text {hitung }}$ untuk variabel disiplin $\left(\mathrm{X}_{1}\right)$ sebesar 2,117 motivasi $\left(\mathrm{X}_{2}\right)$ sebesar 2,230, pelatihan $\left(\mathrm{X}_{3}\right)$ sebesar 1,695 dengan $\mathrm{T}_{\text {tabel }}$ sebesar 2,063 menunjukkan bahwa variable disiplin dan motivasi mempengaruhi kinerja karyawan, sedangkan variable pelatihan tidak mempengaruhi kinerja karyawan. Hasil Koefisien Determinasi (adjusted $\mathrm{R}^{2}$ ) yang diperoleh sebesar 0,797 itu artinya Kinerja Karyawan dipengaruhi oleh variabel: disiplin, motivasi, dan pelatihan kerja.
\end{abstract}

Kata kunci : disiplin, motivasi, pelatihan, kinerja karyawan. 


\section{PENDAHULUAN}

Sumber daya manusia mempunyai peran utama dalam setiap kegiatan perusahaan. Semua tindakan yang diambil dalam setiap kegiatan diprakarsai dan ditentukan oleh manusia yang menjadi anggota perusahaan.

Keberhasilan suatu organisasi dipengaruhi oleh kinerja individu pegawainya, suatu organisasi akan berupaya untuk meningkatkan kinerja pegawainya dengan harapan dan tujuan perusaan dapat tercapai dengan efektif dan efisien. Selain itu suasana tempat kerja yang nyaman, pemberi motivasi, penciptaan disiplin kerja yang baik dan di dukung dengan pelatihan kerja yang sesuai kepada setiap karyawan, akan dapat meningkatkan semangat karyawan dalam bekerja.

Kinerja pada umumnya adalah hasil kerja yang dicapai oleh seseorang atau kelompok orang dalam suatu organisasi, sesuai dengan wewenang dan tanggung jawab masing masing dalam rangka upaya mencapai tujuan organisasi bersangkutan, secara legal dan tidak melanggar hukum dan sesuai moral ataupun etika (Mathis dan Jackson, 2009:113). Kinerja yang tinggi dapat dibentuk dengan adanya kesadaran setiap pimpinan perusahaan untuk memberikan dukungan kepada karyawan berupa keikutsertaan pemimpin dalam memberikan arahan mengenai pekerjaan yang dilakukan oleh setiap karyawan, dengan demikian karyawan dapat lebih memahami mengenai tanggung jawab pekerjaan yang mereka lakukan.

Dengan demikian, kinerja merupakan hal yang penting bagi organisasi atau perusahaan serta dari pihak pegawai itu sendiri. Rendahnya tingkat kinerja karyawan dalam suatu perusahaan dapat dilihat dari besar gaji maupun tunjangan yang diberikan oleh perusahaan dengan besarnya tanggung jawab pekerjaan yang dilakukan selain itu tingkat kehadiran ditempat kerja yang diakibatkan oleh kurangnya disiplin kerja karyawan serta penggunaan waktu secara tidak efektif dalam melaksanakan pekerjaan juga dikatakan sebagai rendahnya tingkat kinerja karyawan.

Kedisiplin adalah kesadaran seseorang mentaati semua peraturan perusahaan, badan atau organisasi dan norma-norma sosial yang berlaku. Dengan adanya kedisiplinan dalam bekerja, pegawai yang berada dalam perusahaan otomatis akan meningkat ke efektifannya dalam dunia pekerjaan. Maka dari itu kedisiplinan sangat diperlukan dalam dunia kerja.

Karyawan dituntut untuk mampu menyelesaikan tugas dan tanggung jawabnya secara efektif dan efisien. keberhasilan karyawan dapat diukur melalui kepuasan konsumen, dan berkurangnya jumlah keluhan. Kinerja karyawan PT. Bank BRI Persero Kalianda dapat diukur melalui penyelesaian tugasnya secara efektif dan efisien serta melakukan peran dan fungsinya dan itu semua berhubungan linear dan berhubungan positif bagi keberhasilan suatu perusahaan.

Pelatihan kerja merupakan salah satu hal yang dibutuhkan perusahaan dan merupakan salah satu unsur penting demi kemajuan perusahaan tersebut. Dalam melaksanakan pelatihan kerja tersebut perusahaan bisa menggunakan pengalaman dan pengetahuan tentang bidang tersebut. Pelatihan kerja merupakan salah satu sarana bagi karyawan untuk dapat mempelajari dan meningkatkan keterampilan yang berguna bagi karyawan dalam menjalankan tugas-tugas di perusahaan tersebut.

Bank Rakyat Indonesia (BRI) adalah salah satu bank milik pemerintah yang terbesar di Indonesia. Lembaga tersebut berdiri tanggal 16 Desember 1895 , yang kemudian dijadikan sebagai hari berdirinya BRI. Sejak 1 Agustus 1992 berdasarkan Undang-Undang Perbankan No.7 Tahun 1992 dan Peraturan Pemerintah RI No.21 Tahun 1992 status BRI berubah menjadi Perseroan terbatas.

Kepemilikan BRI saat itu masih 100\% ditangan Pemerintah Republik Indonesia. Pada tahun 2003, Pemerintah Indonesia memutuskan untuk menjual $30 \%$ saham bank ini, sehingga menjadi perusahaan public dengan nama resmi PT. Bank Rakyat Indonesia (Persero) Tbk yang masih digunakan sampai saat ini.

Kinerja karyawan PT. Bank BRI Persero Kalianda dapat diukur melalui penyeselesaian tugasnya secara efektif dan efisien, maka berdasarkan Surat Keputusan Direksi BRI Nokep: S.67-DIR/12/1982 tanggal 2 Desember 1982 ditentukan bahwa hari jadi Bank Rakyat Indonesia adalah tanggal 16 Desember 1895.

Berikut ini adalah tabel yang berisikan mengenai jumlah absensi dari para karyawan yang ada pada PT. Bank BRI Persero Kalianda Tahun 2017.

Tabel 1.1

Tingkat Absensi Karyawan di PT. Bank BRI Persero Kalianda Tahun 2017

\begin{tabular}{|l|c|c|c|c|c|}
\hline \multicolumn{1}{|c|}{ Bulan } & $\begin{array}{c}\text { Jumlah } \\
\text { Hari } \\
\text { Kerja }\end{array}$ & $\begin{array}{c}\text { Jumlah } \\
\text { Karyawan }\end{array}$ & $\begin{array}{c}\text { Total } \\
\text { Hari } \\
\text { Kerja }\end{array}$ & $\begin{array}{c}\text { Jumlah } \\
\text { Hari Absen }\end{array}$ & $\begin{array}{c}\text { Realisasi } \\
\text { (\%) }\end{array}$ \\
\hline Januari & 21 & 36 & 756 & 30 & 4 \\
\hline Februari & 19 & 36 & 684 & 48 & 7,1 \\
\hline Maret & 21 & 36 & 756 & 42 & 5,6 \\
\hline April & 21 & 36 & 756 & 50 & 6,6 \\
\hline Mei & 21 & 36 & 756 & 45 & 5,9 \\
\hline Juni & 22 & 36 & 792 & 38 & 4,8 \\
\hline Juli & 20 & 36 & 720 & 25 & 3,5 \\
\hline Agustus & 22 & 36 & 792 & 52 & 6,6 \\
\hline September & 21 & 36 & 756 & 40 & 5,3 \\
\hline Oktober & 19 & 36 & 684 & 49 & 7,1 \\
\hline November & 22 & 36 & 792 & 36 & 4,5 \\
\hline Desember & 21 & 36 & 756 & 45 & 5,9 \\
\hline Rata-rata & $\mathbf{2 1}$ & $\mathbf{3 6}$ & $\mathbf{7 5 0}$ & $\mathbf{3 0}$ & $\mathbf{5 , 5}$ \\
\hline
\end{tabular}


Perhitungan tingkat absensi karyawan diperoleh dengan rumus :

$$
\text { Tingkat absensi }=\times 100 \%
$$

Berdasarkan tabel diatas, terlihat bahwa absensi karyawan tertinggi terjadi pada bulan Oktober 2017 yaitu sebesar $7,1 \%$ dan tingkat absensi terendah terjadi pada bulan Juli 2017 yaitu sebesar 3,5\%. Rata-rata tingkat absensi karyawan periode Januari 2017 - Desember 2017 sebesar 5,5 \%. Dalam hal ini penyebab ketidakhadiran karyawan adalah karena sakit, ada keperluan, dan tanpa alasan yang jelas.

Dilihat dari table 1.1 masih ada permasalahan yang harus diperbaiki oleh PT Bank BRI Persero Kalianda dalam hal disiplin kerja dari para karyawan itu sendiri. Tingginya tingkat ketidakhadiran karyawan merupakan indikasi dari turunnya semangat kerja karyawan sebagai rendahnya motivasi kerja yang pada akhirnya dapat menurunkan kinerja karyawan.

Tabel 1.2

Tingkat Pendidikan Karyawan di PT. Bank BRI (Persero) Kalianda

\begin{tabular}{|c|c|c|c|c|}
\hline No. & Tingkat Pendidikan & Laki-laki & Perempuan & Jumlah \\
\hline 1. & S2 & 2 & 4 & 6 \\
\hline 2. & S1 & 10 & 10 & 20 \\
\hline 3. & D3 & 4 & 2 & 6 \\
\hline 4. & SMA & 3 & - & 3 \\
\hline 5. & SMP & 1 & - & 1 \\
\hline & Total & $\mathbf{2 0}$ & $\mathbf{1 6}$ & $\mathbf{3 6}$ \\
\hline
\end{tabular}

(Sumber : PT. Bank BRI Persero Kalianda)

Berdasarkan tabel 1.2 diatas menjelaskan latar belakang tingkat pendidikan Karyawan Pada PT. Bank BRI Persero Kalianda peneliti melakukan pra survey dengan HRD dari PT. Bank BRI Persero Kalianda. Menurut keterangan dari HRD PT. Bank BRI Persero Kalianda diketahui bahwa selama ini rendahnya disiplin kerja dapat disebabkan oleh beberapa faktor yang tersaji pada tabel dibawah ini.

Tabel 1.3

Hasil Pra Survei Mengenai Penyebab Rendahnya Disiplin Kerja KaryawanPT. Bank BRI Persero Kalianda

\begin{tabular}{|l|l|c|c|}
\hline No & $\begin{array}{c}\text { Faktor Penyebab Rendahnya Disiplin } \\
\text { Kerja Karyawan }\end{array}$ & Jumlah Jawaban & Persentasi \% \\
\hline $\mathbf{1}$ & $\begin{array}{l}\text { Terkait sikap: kurangnya kesadaran } \\
\text { karyawan dalam melaksanakan tugas }\end{array}$ & 12 & 35 \\
\hline $\mathbf{2}$ & $\begin{array}{l}\text { Terkait norma: karyawan sering } \\
\text { melakukan pelanggaran peraturan }\end{array}$ & 15 & 40 \\
\hline $\mathbf{3}$ & $\begin{array}{l}\text { Terkait tanggung jawab: kurangnya } \\
\text { kemampuan dalam melaksanakan } \\
\text { tugas }\end{array}$ & 9 & 25 \\
\hline \multicolumn{2}{|c|}{ Total } & $\mathbf{3 6}$ & $\mathbf{1 0 0}$ \\
\hline
\end{tabular}

(Sumber: Hasil Survei dari HRDPT. Bank BRI Persero Kalianda)
Hasil survey tersebut menunjukkan sebanyak 12 orang $(35 \%)$ rendahnya disiplin kerja karyawan karena kurangnya kesadaran karyawan dalam melaksanakan tugas, sebanyak 15 orang $(40 \%)$ mengatakan bahwa rendahnya disiplin kerja karyawan karena karyawan sering melakukan pelanggaran peraturan. Sementara itu, sebanyak 9 orang $(25 \%)$ mengatakan bahwa rendahnya disiplin kerja karyawan karena kurangnya kemampuan karyawan dalam melaksanakan tugas.

Kemudian mengenai penyebab menurunnya motivasi kerja karyawan PT. Bank BRI Persero Kalianda diindikasikan dengan beberapa faktor yang tersaji pada table di bawah ini:

Tabel 1.4

Hasil Pra Survei Mengenai Penyebab Rendahnya Motivasi Kerja KaryawanPT. Bank BRI Persero Kalianda

\begin{tabular}{|l|c|c|c|}
\hline No & $\begin{array}{c}\text { Faktor Penyebab Rendahnya Motivasi } \\
\text { Kerja Karyawan }\end{array}$ & Jumlah Jawaban & Persentasi \% \\
\hline $\mathbf{1}$ & Tidak adanya kebutuhan berprestasi & 17 & 45 \\
\hline $\mathbf{2}$ & Tidak adanya kebutuhan besosialisasi & 5 & 15 \\
\hline $\mathbf{3}$ & Tidak adanya kebutuhan kekuasan & 14 & 40 \\
\hline \multicolumn{2}{r|}{ Total } & $\mathbf{3 6}$ & $\mathbf{1 0 0}$ \\
\hline
\end{tabular}

(Sumber: Hasil Survei dari HR DPT. Bank BRI Persero Kalianda)

Hasil survei tersebut menunjukkan sebanyak 17 orang (45\%) mengatakan bahwa menurunnya motivasi kerja karyawan karena tidak adanya kebutuhan berprestasi dalam diri karyawan, sebanyak 5 orang $(15 \%)$ mengatakanbahwa menurunnya motivasi kerja karyawan karena tidakadanya kebutuhan bersosialisasi dalamdiri karyawan. Sementara itu, sebanyak 14 orang (40\%) mengatakan bahwa menurunnya motivasi kerja karyawan karena tidak adanya kebutuhan kekuasan dalam diri karyawan. Menurunnya pelatihan kerja karyawan PT. Bank BRI Persero Kalianda dapat dilihat dalam table berikut ini:

Tabel 1.5

Hasil Pra Survei Mengenai Penyebab Rendahnya PelatihanKerja Karyawan PT. Bank BRI Persero Kalianda

\begin{tabular}{|c|c|c|c|}
\hline No & $\begin{array}{c}\text { Faktor Penyebab Rendahnya Pelatihan } \\
\text { Kerja Karyawan }\end{array}$ & Jumlah Jawaban & Persentasi \% \\
\hline 1 & $\begin{array}{l}\text { Ketidaksesuaian jadwal pelaksanaan } \\
\text { kegiatan pelatihan }\end{array}$ & 21 & 75 \\
\hline $\mathbf{2}$ & $\begin{array}{l}\text { Ketidaktertarikan mengikuti kegiatan } \\
\text { Pelatihan }\end{array}$ & 15 & 25 \\
\hline \multicolumn{1}{|c|}{ Total } & $\mathbf{3 6}$ & $\mathbf{1 0 0}$ \\
\hline
\end{tabular}

(Sumber: Hasil Survei dari HRDPT. Bank BRI Persero Kalianda) 
Hasil survei tersebut menunjukkan sebanyak 21 orang (75\%) mengatakan bahwa menurunnya pelatihan kerja karyawan karena ketidaksesuaian jadwal pelaksanaan kegiatan pelatihan, sebanyak 15 orang $(25 \%)$ mengatakan bahwa menurunnya pelatihan kerja karyawan karena ketidaktertarikan mengikuti kegiatan Pelatihan.

Berdasarkan survei pendahuluan, penulis menemukan adanya kekurangan mentaati tata tertib, peraturanperaturan, tugas serta tanggung jawab karyawan yang mengindikasikan kurang optimalnya disiplin, motivasi dan pelatihan kerja. Maka dalam hal ini menimbulkan pemikiran bagaimana keseluruhan faktor tersebut saling berkesinambungan sehingga mempengaruhi kinerja karyawan.

Sehubungan dengan masalah yang diuraikan diatas, peneliti tertarik untuk melakukan penelitian mengenai disiplin kerja, motivasi kerja, dan pelayihan kerja pada PT Bank BRI Persero Kalianda dengan judul: Pengaruh Disiplin Motivasi dan Pelatihan Kerja terhadap Kinerja Karyawan (Studi pada Karyawan Tetap PT. Bank BRI Persero Kalianda) .

Identifikasi masalah

Karyawan belum bisa disiplin dalam bekerja, kurang termotivasinya karyawan dalam melakukan tugas dan pelatihan kerja yang kurang maksimal pada perusahaan.

\section{Rumusan Masalah}

Apakah Disiplin Motivasi dan Pelatihan berpengaruh positif terhadap kinerja karyawan pada PT. BANK BRI (Persero) Kalianda?

\section{Tinjauan Pustaka Dan Kerangka Konseptual Pengertian Manajemen}

Menurut Melayu SP. Hasibuan, MSDM adalah ilmu dan seni mengatur hubungan dan peranan tenaga kerja agar efektif dan efisien membantu terwujudnya tujuan perusahaan, karyawan dan masyarakat.

Menurut Mutiara S. Panggabean, MSDM adalah proses yang terdiri dari perncanaan, pengorganisasian, pimpinan dan pengendalian kegiatan-kegiatan yang berkaitan dengan analisis pekerjaan, evaluasi pekerjaan, pengadaan,

pengembangan, kompensasi, promosi dan pemutusan hubungan kerja guna mencapai tujuan yang telah ditetapkan.

Menurut Henry Simamora, MSDM adalah sebagai pendayagunaan, pengembangan, penilaian, pemberian balasan jasa, dan pengelolaan terhadap individu anggota organisasi atau kelompok bekerja. MSDM juga menyangkut desain atau implementasi sistem perencaan, penyusunan personalia, pengembangan karyawan, pengelolaan karier, evaluasi kerja, kompensasi karyawan dan hubungan perburuhan yang mulus.

\section{Disiplin Kerja}

Disiplin adalah sikap dan perilaku kepatuhan terhadap peraturan organisasi, prosedur kerja, kode etik dan norma budaya organisasi lainnya yang harus dipatuhi dalam memproduksi suatu produk dan melayani konsumen organisasi (Wirawan, 2009).

\section{Motivasi Kerja}

Setiap pegawai memiliki kebutuhan yang berbedabeda. Pentingnya motivasi karena merupakan hal yang menyebabkan, menyalurkan dan mendukung perilaku manusia agar giat an antusias mencapai hasil yang memuaskan.Motivasi berasal dari Bahasa Latin Mavere yang berarti dorongan atau daya penggerak.

Pelatihan kerja

Menurut Mondy (2008 : 210), Pelatihan adalah jantung dari upaya berkelanjutan untuk meningkatkan kompetensi karyawan dan kinerja organisasi.

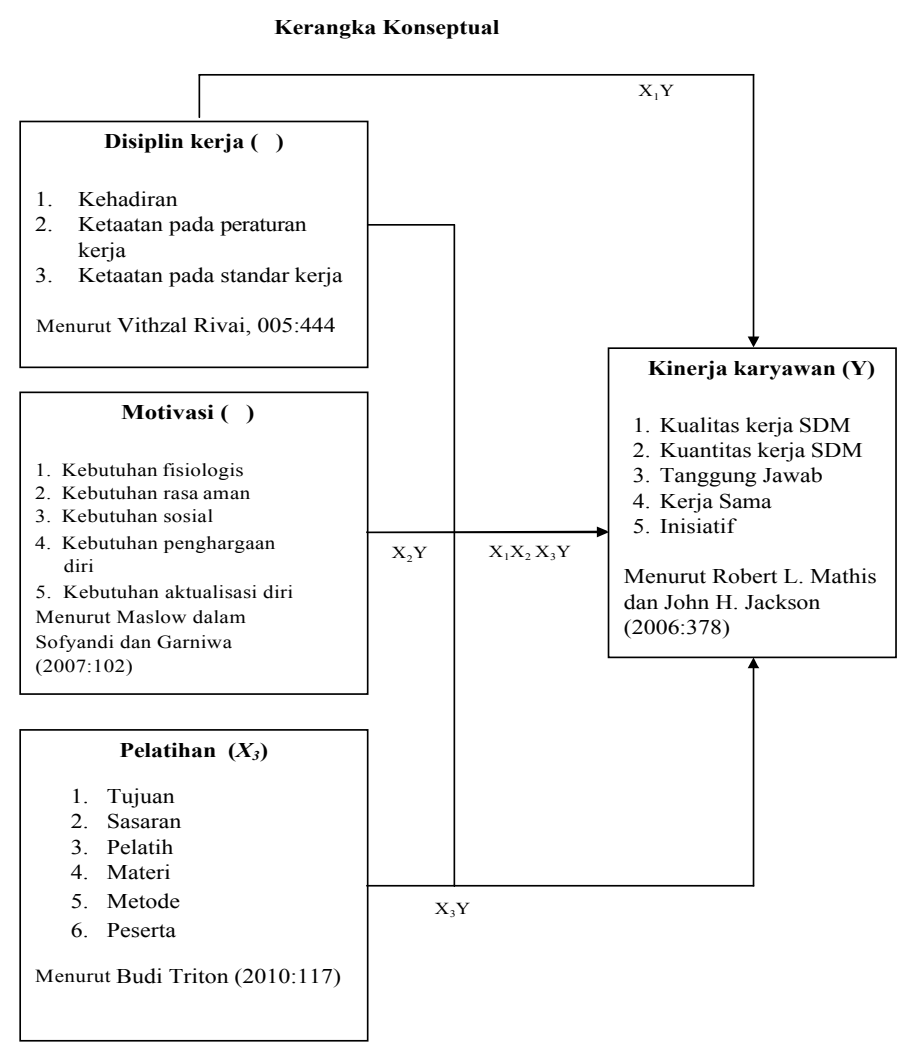

\section{Metode Penelitian Jenis Penelitian}

1. Penelitian Lapangan (Field Research)

Penelitian lapangan adalah penelitian yang dilakukan dalam kehidupan sebenarnya dengan terjun langsung ke masyarakat, ke objek penelitian atau sasaran penelitian untuk menemukan secara spesifik dan realistic tentang suatu yang terjadi pada suatu keadaan ditengah masyarakat.Dalam hal ini penulis terjun langsung ke objek yang diteliti yaitu pada PT. Bank BRI Persero Kalianda.

2. Penelitian Kepustakaan (Library Research)

Penelitian Kepustakaan adalah penelitian yang dilakukan dengan cara mencari berbagai literature 
yang berhubungan dengan penelitian untuk memperoleh teori-teori yang relevan dengan penelitian yang dilakukan, dengan jalan mempelajari buku-buku, literature-literature atau pun karangan ilmiah yang berhubungan dengan masalah yang diteliti.

\section{Desain Penelitian}

Desain penelitian ini berupa desain penelitian Deskriptif. Metode penelitian deskriptif adalah prosedur atau cara pemecahan masalah dengan cara menggambarkan atau melukiskan fenomena, keadaan, peristiwa atau sesuatu yang sedang berlangsung pada saat sekarang berdasarkan pada fakta-fakta yang tampak sebagaimana adanya. Penelitian ini menjelaskan hubungan kausal antara variabel variabel melalui pengujian hipotesis. analisis dan pembahasan

\section{Deskripsi Responden}

Responden yang menjadi objek penelitian adalah karyawan di PT. Bank BRI Persero Kalianda dengan jumlah populasi sebanyak 36 responden. Penyebaran kuesioner kepada 36 responden telah lengkap dikumpulkan, dengan demikian tanggapan responden dalam penelitian ini sebesar $100 \%$. Tahapan setelah pengumpulan kuesioner adalah pemeriksaan kelengkapan jawaban responden dan isian kuesioner, hasil pemeriksaan jawaban responden dinyatakan layak digunakan analisa data.

\section{Deskripsi Responden Berdasarkan Jenis Kelamin}

Karakteristik responden menurut jenis kelamin ditunjukkan pada tabel dibawah ini :

Tabel 4.1

Distribusi Frekuensi Responden Berdasarkan Jenis Kelamin di PT. Bank BRI Persero Kalianda

\begin{tabular}{|c|l|c|c|}
\hline No & Jenis Kelamin & Frekuensi & Persentasi (\%) \\
\hline 1 & Laki - laki & 14 & 38 \\
\hline 2 & Prempuan & 22 & 62 \\
\hline & Jumlah & 36 & 100 \\
\hline
\end{tabular}

Sumber : Data diolah (2019)

Berdasarkan hasil pada tabel 4.1 menunjukan jumlah responden laki-laki 14 karyawan atau presentasi (20\%) sedangkan jumlah responden Perempuan berjumlah 22 karyawan atau presentasi (80\%). Maka hasil dari deskripsi diatas menunjukan bahwa responden didominasi oleh Perempuan.

\section{Deskripsi Responden Berdasarkan Jenjang Pendidikan}

Jika karakteristik responden dibedakan menurut tingkat pendidikan, maka dapat ditunjukan pada tabel 4.2 sebagai berikut:
Tabel 4.2

Distribusi Frekuensi Responden Berdasarkan Jenjang Pendidikan di PT. Bank BRI Persero Kalianda

\begin{tabular}{|c|l|c|c|}
\hline Nomor & Tingkat Pendidikan & Frekuensi & Persentasi (\%) \\
\hline 1 & SMP & 0 & 0 \\
\hline 2 & SMA & 4 & 12 \\
\hline 3 & D-3 & 5 & 14 \\
\hline 4 & S-1 & 22 & 60 \\
\hline 5 & S-2 & 5 & 14 \\
\hline \multicolumn{2}{|c|}{ Jumlah } & 36 & 100 \\
\hline
\end{tabular}

Sumber : Data diolah (2019)

Berdasarkan tabel 4.2 menunjukan karyawan PT. Bank BRI Persero Kalianda yang berpendidikan SMA berjumlah 4 karyawan atau persentasi (5\%), D-3 berjumlah 5 karyawan atau presentasi (10\%) sedangkan S1 berjumlah 22 karyawan atau persentasi (75\%) dan S2 berjumlah 5 karyawan atau persentasi (10\%). Maka dari hasil deskripsi diatas menunjukan bahwa responden didominasi oleh tingkat pendidikan S1.

\section{Uji validitas}

Uji validitas akan menguji masing-masing variabel yang akan digunakan dalam penelitian ini, dimana keseluruhan variabel penelitian memuat 40 pertanyaan yang harus dijawab oleh responden. Butir pernyataan dikatakan valid jika $r$ hitung lebih besar dari $r$ tabel dengan taraf signifikan 5\% adapun kriteria dalam menentukan valid atau tidaknya suatu pertanyaan dalam penelitian ini $\mathrm{R}$ tabel $=0,3291$. Berdasarkan analisis yang telah dilakukan maka hasil pengujian validitas dapat di tunjukan sebagai berikut:

Tabel 4.3 Hasil Uji Validitas

\begin{tabular}{|c|c|c|c|c|}
\hline No & Indikator & R hitung & R tabel & Keterangan \\
\hline \multirow[t]{10}{*}{1} & Disiplin Kerja & & & \\
\hline & ${ }_{-}^{-P_{1}} \mathrm{P2}$ & $\begin{array}{l}0,355 \\
0,505\end{array}$ & $\begin{array}{l}0,329 \\
0,329\end{array}$ & $\begin{array}{l}\text { Valid } \\
\text { Valid }\end{array}$ \\
\hline & - P3 & 0,402 & 0,329 & Valid \\
\hline & $\begin{array}{l}-\quad P 4 \\
-\end{array}$ & 0,516 & 0,329 & Valid \\
\hline & $\begin{array}{l}-\quad P 5 \\
-\quad 1\end{array}$ & 0,345 & 0,329 & Valid \\
\hline & - P6 & 0,363 & 0,329 & Valid \\
\hline & $\begin{array}{l}-\quad \text { P7 } \\
\end{array}$ & 0,476 & 0,329 & Valid \\
\hline & $-\quad$ P8 & 0,453 & 0,329 & Valid \\
\hline & - P9 & 0,593 & 0,329 & Valid \\
\hline & - P10 & 0,620 & 0,329 & Valid \\
\hline \multirow[t]{11}{*}{2} & Motivasi Kerja & & & \\
\hline & - P11 & 0,354 & 0,329 & Valid \\
\hline & $\begin{array}{l}-\quad P 12 \\
-\end{array}$ & 0,367 & 0,329 & Valid \\
\hline & $-\quad$ P13 & 0,569 & 0,329 & Valid \\
\hline & $-\quad$ P14 & 0,502 & 0,329 & Valid \\
\hline & $\begin{array}{l}-\quad \text { P15 } \\
-\quad 1\end{array}$ & 0,421 & 0,329 & Valid \\
\hline & - $\quad$ P16 & 0,365 & 0,329 & Valid \\
\hline & P17 & 0,394 & 0,329 & Valid \\
\hline & - P18 & 0,567 & 0,329 & Valid \\
\hline & - $\quad$ P19 & 0,493 & 0,329 & Valid \\
\hline & $-\quad P 20$ & 0,472 & 0,329 & Valid \\
\hline \multirow[t]{11}{*}{3} & Pelatihan Kerja & & & \\
\hline & $-\quad P 21$ & 0,398 & 0,329 & Valid \\
\hline & - $\quad$ P22 & 0,365 & 0,329 & Valid \\
\hline & $-\quad$ P23 & 0,663 & 0,329 & Valid \\
\hline & 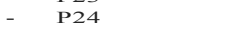 & 0,407 & 0,329 & Valid \\
\hline & - P25 & 0,441 & 0,329 & Valid \\
\hline & P26 & 0,377 & 0,329 & Valid \\
\hline & P27 & 0,392 & 0,329 & Valid \\
\hline & P28 & 0,554 & 0,329 & Valid \\
\hline & P29 & 0,504 & 0,329 & Valid \\
\hline & P3O & 0,349 & 0,329 & Valid \\
\hline \multirow[t]{10}{*}{4} & Kinerja Karyawan & & & \\
\hline & - P31 & 0,680 & 0,329 & Valid \\
\hline & $\begin{array}{l}-\quad \text { P32 } \\
\end{array}$ & 0,634 & 0,329 & Valid \\
\hline & $\begin{array}{l}-\quad \text { P33 } \\
-\quad \text { P34 }\end{array}$ & $\begin{array}{l}0,504 \\
0,377\end{array}$ & $\begin{array}{l}0,329 \\
0,329\end{array}$ & $\begin{array}{l}\text { Valid } \\
\text { Valid }\end{array}$ \\
\hline & $\begin{array}{l}1 \\
-\quad \text { P35 }\end{array}$ & 0,604 & 0,329 & Valid \\
\hline & P36 & 0,518 & 0,329 & Valid \\
\hline & P37 & 0,337 & 0,329 & Valid \\
\hline & $\begin{array}{l}-\quad \text { P38 } \\
\text { - }\end{array}$ & 0,451 & 0,329 & Valid \\
\hline & P39 & 0,399 & 0,329 & Valid \\
\hline & P40 & 0,387 & 0,329 & Valid \\
\hline
\end{tabular}

Sumber : Data diolah (2019) 
Berdasarkan tabel diatas maka dapat dikatakan bahawa, semua indikator yang digunakan untuk mengukur variabel-variabel dalam penelitian ini mempunyai koefisien korelasi yang lebih besar dari nilai $\mathrm{R}$ tabel. Dengan demikian maka semua indikator dinyatakan valid.

\section{Uji Reliabilitas}

Uji reliabilitas adalah suatu alat ukur kuisoner yang merupakan alat pengukuran konstruktur atau variabel. Uji reliabilitas adalah tingkat kestabilan suatu alat pengukur dalam mengukur suatu gejala atau kejadian. Semakin tinggi reabilitas suatu alat pengukur, semakin stabil pula alat pengukur tersebut. Suatu variabel dikatakan reliabel jika memberikan nilai Cronbach Alpha $>0,60$. Berikut ini hasil pengujian reliabilitas disajikan dalam bentuk tabel:

Tabel 4.4 Hasil Uji Reliabilitas

\begin{tabular}{|l|c|c|c|}
\hline \multicolumn{1}{|c|}{ Variabel } & $\begin{array}{c}\text { Cronbach's } \\
\text { Alpha }\end{array}$ & $\begin{array}{c}\text { Standar } \\
\text { Loading } \\
\text { Factor }\end{array}$ & Kesimpulan \\
\hline Disiplin Kerja & 0,725 & 0,60 & Reliabel \\
\hline Motivasi Kerja & 0,618 & 0,60 & Reliabel \\
\hline Pelatihan Kerja & 0,643 & 0,60 & Reliabel \\
\hline Kinerja Karyawan & 0,746 & 0,60 & Reliabel \\
\hline \multicolumn{2}{|c|}{ Sumber :Datadiolah(2019) }
\end{tabular}

\section{Analisa Data}

\section{Analisis Data Kualitatif}

Analisis data kualitatif berupa uraian data yang diperoleh dari penelitian lapangan yang kemudian akan dikemukakan dalam bentuk tabel beserta penyelesaiannya (Sutrisno Eds, 2013:178). Analisa data kualitatif yang berupa uraian data yang diperoleh dari penelitian lapangan, kemudian akan dikemukakan dalam bentuk tabel beserta penyelesaiannya. Data yang berhasil dikumpulkan tersebut selanjutnya akan digolongkan dan disajikan dalam bentuk tabel beserta penguraian dan penyelesaiannya.

Cara penggolongan data pada tabel tersebut dengan menggunakan rumus Interval

Keterangan :

$$
\mathrm{I}=\frac{(N T-N R)}{K}
$$

$\begin{array}{ll}\text { NT } & \text { : Nilai Tertinggi } \\ \text { NR } & \text { : Nilai Terendah } \\ \text { K } & \text { : Kategori } \\ \text { I } & \text { : Interval }\end{array}$

Dalam penelitian ini, peneliti menyebarkan 36 angket untuk 36 responden dimana dalam angket tersebut terdapat 40 item pertanyaan dari 19 indikator yang didapat dari variable X1, X2,X3 dan Y. Dari skor yang diperoleh dikelompokkan menjadi 5 kategori yaitu:
1. Sangat Baik
2. Baik

3. Cukup Baik

4. Tidak Baik

5. Sangat Tidak Baik

\section{Analisis Variabel Motivasi Kerja (Variabel Bebas X1)}

Rekapitulasi hasil pernyataan variabel Motivasi Karyawan PT. Bank BRI Persero Kalianda dapat dilihat pada tabel 4.5 di bawah ini.

$$
\begin{aligned}
& \mathrm{NT}=50 \\
& \mathrm{NR}=10 \\
& \mathrm{~K}=5 \\
& \mathrm{I}=\frac{(N T-N R)}{K} \\
& \mathrm{I}=\frac{(50-10)}{5} \\
& \mathrm{I}=8
\end{aligned}
$$

Dengan demikian dapat diketahui skor pengelompokannya sebagai berikut:

\begin{tabular}{|l|l|}
\hline Interval & \multicolumn{1}{|c|}{ Kategori } \\
\hline $42-50$ & Sangat Baik \\
$34-41$ & Baik \\
$26-33$ & Cukup Baik \\
$18-25$ & Tidak Baik \\
$10-17$ & Sangat Tidak Baik \\
\hline
\end{tabular}

Tabel 4.5

Distribusi Frekuensi Skor Disiplin Kerja Berdasarkan Pernyataan Responden

\begin{tabular}{|c|c|l|c|c|}
\hline No & Interval & Kategori & Frekuensi & Persentasi \% \\
\hline 1 & $42-50$ & Sangat Baik & 12 & 33,33 \\
\hline 2 & $34-41$ & Baik & 21 & 58,33 \\
\hline 3 & $26-33$ & Cukup Baik & 3 & 7,33 \\
\hline 4 & $18-25$ & Tidak Baik & 0 & 0 \\
\hline 5 & $10-17$ & Sangat Tidak Baik & 0 & 0 \\
\hline & & Jumlah & $\mathbf{3 6}$ & $\mathbf{1 0 0}$ \\
\hline
\end{tabular}

Berdasarkan data tabel 4.5 di atas, dari 36 orang responden penelitian yang menyatakan bahwa variabel Disiplin Kerjadi PT.Bank BRI Persero Kalianda "sangat baik" sebanyak 12 orang atau sekitar 33\%, yang menyatakan "baik" sebanyak 21 orang atau sekitar 59\%, yang menyatakan "cukup baik" sebanyak 3 orang atau sekitar $8 \%$, kemudian yang menyatakan "tidak baik" dan "sangat tidak baik" tidak ada. Dari hasil tersebut banyak didominasi nilai baik dari disiplin kerja yang sudah baik dengan persentasi 58,33\%.

Berdasarkan hasil jawaban responden atas kuisioner variabel Disiplin Kerjapada karyawan PT.Bank BRI Persero Kaliandadi Bandar Lampung diperoleh hasil persentasi dan kriteria jawaban sebagai berikut: 


$$
\begin{aligned}
I & =\frac{(\% \max -\% \min )}{K} \\
I & =\frac{(100-20)}{5} \\
I & =16 \%
\end{aligned}
$$

Dengan demikian dapat diketahui skor pengelompokannya sebagai berikut:

\begin{tabular}{|c|l|}
\hline Interval & \multicolumn{1}{|c|}{ Kategori } \\
\hline $84-100$ & Sangat Baik \\
$68-83$ & Baik \\
$52-67$ & Cukup Baik \\
$36-51$ & Tidak Baik \\
$20-35$ & Sangat Tidak Baik \\
\hline
\end{tabular}

Tabel 4.6

Persentase Hasil Penelitian Berdasarkan Indikator Disiplin Kerja (X1)

\begin{tabular}{|l|l|l|l|l|l|}
\hline No & \multicolumn{1}{|c|}{ Indikator } & $\begin{array}{c}\text { Skor } \\
\text { Max }\end{array}$ & $\begin{array}{c}\text { Skor } \\
\text { Riil }\end{array}$ & $\begin{array}{c}\text { Persentasi } \\
(\%)\end{array}$ & Kriteria \\
\hline 1 & $\begin{array}{l}\text { Anda selalu datang ke } \\
\text { tempat kerja sebelum jam } \\
\text { kerja dimulai }\end{array}$ & 180 & 155 & 86,11 & Sangat Baik \\
\hline 2 & $\begin{array}{l}\text { Anda selalu pulangdari } \\
\text { tempat kerja sebelum jam } \\
\text { kerja berakhir }\end{array}$ & 180 & 158 & 87,77 & Sangat Baik \\
\hline 3 & $\begin{array}{l}\text { Anda menggunakan waktu } \\
\text { istirahat dengan tepat }\end{array}$ & 180 & 128 & 71,11 & Baik \\
\hline 4 & $\begin{array}{l}\text { Anda sering tidak masuk } \\
\text { kerja }\end{array}$ & 180 & 137 & 76,11 & Baik \\
\hline 5 & $\begin{array}{l}\text { Anda selalu mengenakan } \\
\text { pakaian sesuai dengan } \\
\text { peraturan perusahaan }\end{array}$ & 180 & 153 & 85,00 & Sangat Baik \\
\hline 6 & $\begin{array}{l}\text { Anda selalu mengenakan } \\
\text { atribut sesuai dengan } \\
\text { peraturan perusahaan }\end{array}$ & 180 & 146 & 81,11 & Baik \\
\hline 7 & $\begin{array}{l}\text { Saya selalu merapikan } \\
\text { peralatan kerja setelah } \\
\text { pekerjaan selesai }\end{array}$ & 180 & 93 & 51,66 & Cukup Baik \\
\hline 8 & $\begin{array}{l}\text { Pekerjaan selisai tepat } \\
\text { waktu }\end{array}$ & 180 & 147 & 81,66 & Baik \\
\hline 9 & $\begin{array}{l}\text { Selalu menaati peraturan } \\
\text { yang ditetapkan oleh } \\
\text { perusahaan }\end{array}$ & 180 & 143 & 79,44 & Baik \\
\hline 10 & $\begin{array}{l}\text { Saya melaksanakan semua } \\
\text { aturan jabatan yang } \\
\text { ditetapkan } \\
\text { perusahaan }\end{array}$ & 180 & 149 & 82,77 & Baik \\
\hline Rata-Rata & 180 & 140,9 & 78,33 & Baik \\
\hline
\end{tabular}

Sumber :Datadiolah (2019)

Berdasarkan tabel diatas dapat dijelaskan bahwa nilai rata-rata jawaban responden atas seluruh item pertanyaan tentang variabel Disiplin Kerja yang diukur melalui indikator: Kehadiran, Ketaatan pada peraturan, dan Ketaatan pada standar kerja adalah sebesar 140,9 atau setara dengan 78,33\% dengan kriteria "Baik".

Hal ini menggambarkan bahwa secara umum responden memberikan penilaian yang baik terhadap Disiplin Kerja di PT.Bank BRI Persero Kalianda.
Dari 10 indikator pertanyaan disiplin kerja terdapat jawaban "sangat baik", tentang waktu pulang kerja dengan presentase $87,77 \%$. Jawaban cukup baik tentang merapihkan peralatan kerja setelah pekerjaan selesai dengan presentase $51,66 \%$ dan jawaban baik tentang melaksanakan aturan yang ditetapkan perusahaan dengan persentasi $82,77 \%$.

\section{Analisis Variabel Motivasi Kerja (Variabel Bebas X2)}

Dari hasil perhitungan interval kelas dan skor ratarata tersebut dapat disusun tabel distribusi frekuensi berdasarkan sebaran skor responden sebagai berikut :

Tabel 4.7

Distribusi Frekuensi Skor Motivasi Kerja Berdasarkan Pernyataan Responden

\begin{tabular}{|c|c|l|c|c|}
\hline No & Interval & Kategori & Frekuensi & Persentasi \% \\
\hline 1 & $42-50$ & Sangat Baik & 6 & 16,66 \\
\hline 2 & $34-41$ & Baik & 27 & 75,00 \\
\hline 3 & $26-33$ & Cukup Baik & 3 & 8,33 \\
\hline 4 & $18-25$ & Tidak Baik & 0 & 0 \\
\hline 5 & $10-17$ & Sangat Tidak Baik & 0 & 0 \\
\hline & & Jumlah & $\mathbf{3 6}$ & $\mathbf{1 0 0}$ \\
\hline
\end{tabular}

Sumber :Datadiolah (2019)

Berdasarkan data tabel 4.7 di atas, dari 36 orang responden penelitian yang menyatakan bahwa variabel Disiplin Kerjadi PT.Bank BRI Persero Kalianda "sangat baik" sebanyak 6 orang atau sekitar $17 \%$, yang menyatakan "baik" sebanyak 27 orang atau sekitar $75 \%$, yang menyatakan "cukup baik" sebanyak 3 orang atau sekitar 8\%, kemudian yang menyatakan "tidak baik" dan "sangat tidak baik" tidak ada.

Dari hasil tersebut didomonasi nilai baik dari motivasi kerja yang sudah baik dengan persentasi $75,00 \%$.

Berdasarkan hasil jawaban responden atas kuisioner variabel Motivasi Kerjapada karyawan PT.Bank BRI Persero Kaliandadiperoleh hasil persentasi dan kriteria jawaban sebagai berikut: 
Tabel 4.8

\section{Hasil Penelitian Berdasarkan Indikator Motivasi} Kerja (X2)

\begin{tabular}{|c|c|c|c|c|c|}
\hline No & Indikator & $\begin{array}{l}\text { Skor } \\
\text { Max }\end{array}$ & \begin{tabular}{|c|} 
Skor \\
Riil
\end{tabular} & $\begin{array}{l}\text { Persentasi } \\
(\%)\end{array}$ & Kriteria \\
\hline 1 & $\begin{array}{l}\text { Penghasilan yang anda terima } \\
\text { saat ini sudah sangat } \\
\text { memuaskan }\end{array}$ & 180 & 93 & 51,66 & $\begin{array}{l}\text { Tidak } \\
\text { Baik }\end{array}$ \\
\hline 2 & $\begin{array}{l}\text { Fasilitas yang anda terima } \\
\text { sudah memadai }\end{array}$ & 180 & 133 & 73,88 & Baik \\
\hline 3 & $\begin{array}{l}\text { Anda dapat menggunakan } \\
\text { tunjangan kesehatan dengan } \\
\text { lancer }\end{array}$ & 180 & 145 & 80,55 & Baik \\
\hline 4 & $\begin{array}{l}\text { Terealisasinya pemberian } \\
\text { dana pension }\end{array}$ & 180 & 149 & 82,77 & Baik \\
\hline 5 & $\begin{array}{l}\text { Hubungan kerja dengan } \\
\text { sesame rekan kerja berjalan } \\
\text { dengan baik }\end{array}$ & 180 & 153 & 85,00 & $\begin{array}{l}\text { Sangat } \\
\text { Baik }\end{array}$ \\
\hline 6 & $\begin{array}{l}\text { Atasan selalu } \\
\text { mengkomunikasikan dengan } \\
\text { bawahan segala sesuatu yang } \\
\text { berhubungan dengan usaha } \\
\text { pencapaian tugas }\end{array}$ & 180 & 145 & 80,55 & Baik \\
\hline 7 & $\begin{array}{l}\text { Jabatan yang anda terima saat } \\
\text { ini sudah sangat memuaskan }\end{array}$ & 180 & 104 & 57,77 & $\begin{array}{l}\text { Cukup } \\
\text { Baik }\end{array}$ \\
\hline 8 & $\begin{array}{l}\text { Saya giat bekerja karena } \\
\text { adanya kesempatan yang } \\
\text { diberikan perusahaan untuk } \\
\text { menduduki posisi tertentu }\end{array}$ & 180 & 147 & 81,66 & Baik \\
\hline 9 & $\begin{array}{l}\text { Saya ingin mengembangkan } \\
\text { kemampuan saya selama } \\
\text { bekerja diperusahaan }\end{array}$ & 180 & 143 & 79,44 & Baik \\
\hline 10 & $\begin{array}{l}\text { Saya selalu mengemukakan } \\
\text { ide atau gagasan yang } \\
\text { memberikandampakpositif }\end{array}$ & 180 & 149 & 82,77 & Baik \\
\hline & Rata-Rata & 180 & 136,1 & 75,55 & Baik \\
\hline
\end{tabular}

Sumber :Datadiolah (2019)

Berdasarkan tabel diatas dapat dijelaskan bahwa nilai rata-rata jawaban responden atas seluruh item pertanyaan tentang variabel Motivasi Kerja yang diukur melalui indikator: Kebutuhan fisiologis, Kebutuhan rasa aman, Kebutuhan social, Kebutuhan penghargaan diri,dan kebutuhan aktualisasi diri pada adalah sebesar 136,1 atau setara dengan 75,55\% dengan kriteria "Baik". Hal ini menggambarkan bahwa secara umum responden memberikan penilaian yang baik terhadap Motivasi Kerja di PT.Bank BRI Persero Kalianda.

Dari 10 indikator pertanyaan motivasi kerja terdapat jawaban sangat baik tentang hubungan sesama rekan kerja dengan presentase $85,00 \%$. Jawaban tidak baik tentang penghasilan pekerjaan yang diterima dengan persentasi $51,66 \%$. Dan jawaban yang cukup baik tentang jabatan yang diterima dengan persentasi $57,77 \%$.

\section{Analisis Variabel Pelatihan Kerja (Variabel Bebas X3)}

Dari hasil perhitungan interval kelas dan skor ratarata tersebut dapat disusun tabel distribusi frekuensi berdasarkan sebaran skor responden sebagai berikut :
Tabel 4.9

Distribusi Frekuensi Skor Pelatihan Kerja Berdasarkan Pernyataan Responden

\begin{tabular}{|c|c|l|c|c|}
\hline No & Interval & \multicolumn{1}{|c|}{ Kategori } & Frekuensi & Persentasi \% \\
\hline 1 & $42-50$ & Sangat Baik & 2 & 5,55 \\
\hline 2 & $34-41$ & Baik & 11 & 30,55 \\
\hline 3 & $26-33$ & Cukup Baik & 22 & 61,11 \\
\hline 4 & $18-25$ & Tidak Baik & 1 & 2,77 \\
\hline 5 & $10-17$ & Sangat Tidak Baik & 0 & 0 \\
\hline & & Jumlah & $\mathbf{3 6}$ & $\mathbf{1 0 0}$ \\
\hline
\end{tabular}

Sumber :Datadiolah (2019)

Berdasarkan data tabel 4.9 di atas, dari 36 orang responden penelitian yang menyatakan bahwa variabel Disiplin Kerjadi PT.Bank BRI Persero Kalianda "sangat baik" sebanyak 2 orang atau sekitar $6 \%$, yang menyatakan "baik" sebanyak 11 orang atau sekitar 30\%, yang menyatakan "cukup baik" sebanyak 22 orang atau sekitar $61 \%$, kemudian yang menyatakan "tidak baik" sebanyak 1 orang atau sekitar 3\%, dan "sangat tidak baik" tidak ada.

Dari hasil tersebut banyak didominasi nilai cukup baik dari pelatihan kerja yang kurang memuaskan dengan persentasi $61,11 \%$.

Berdasarkan hasil jawaban responden atas kuisioner variabel Pelatihan Kerjapada karyawan PT.Bank BRI Persero Kaliandadiperoleh hasil peresentase dan kriteria jawaban sebagai berikut:

Tabel 4.10

Hasil Penelitian Berdasarkan Indikator Pelatihan Kerja (X3)

\begin{tabular}{|c|c|c|c|c|c|}
\hline No & Indikator & $\begin{array}{l}\text { Skor } \\
\text { Max }\end{array}$ & $\begin{array}{c}\text { Skor } \\
\text { Riil }\end{array}$ & $\begin{array}{c}\text { Persentasi } \\
(\%)\end{array}$ & Kriteria \\
\hline 1 & $\begin{array}{l}\text { Pelatihan meningkatkan } \\
\text { keahlian saya dalam bekerja }\end{array}$ & 180 & 106 & 58,88 & $\begin{array}{l}\text { Cukup } \\
\text { Baik }\end{array}$ \\
\hline 2 & $\begin{array}{l}\text { Pelatihan mampu memberikan } \\
\text { pengembangan dalam } \\
\text { menyelesaikan pekerjaan }\end{array}$ & 180 & 124 & 68,88 & Baik \\
\hline 3 & $\begin{array}{l}\text { Pelatihan sesuai dengan } \\
\text { bidang pekerjaan }\end{array}$ & 180 & 119 & 66,11 & $\begin{array}{l}\text { Cukup } \\
\text { Baik }\end{array}$ \\
\hline 4 & $\begin{array}{l}\text { Materi pelatihan pernah saya } \\
\text { dapatkan }\end{array}$ & 180 & 133 & 73,88 & Baik \\
\hline 5 & $\begin{array}{l}\text { Perusahaan mendatangkan } \\
\text { instruktur berkualiikasi }\end{array}$ & 180 & 144 & 80,00 & Baik \\
\hline 6 & $\begin{array}{lr}\text { Pelatihan membuat } & \text { saya } \\
\text { termotivasi } & \text { dalam } \\
\text { pengembangan } & \text { potensi } \\
\text { bekerja } & \\
\end{array}$ & 180 & 96 & 53,33 & $\begin{array}{l}\text { Cukup } \\
\text { Baik }\end{array}$ \\
\hline 7 & $\begin{array}{l}\text { Fasilitas untuk pelatihan } \\
\text { lengkap }\end{array}$ & 180 & 124 & 68,88 & Baik \\
\hline 8 & $\begin{array}{l}\text { Materi yang disampaikan } \\
\text { terpenuhi }\end{array}$ & 180 & 122 & 67,77 & $\begin{array}{l}\text { Cukup } \\
\text { Baik }\end{array}$ \\
\hline 9 & $\begin{array}{l}\text { Pelatihan membangkitkan rasa } \\
\text { ingin tahu terhadap masalah } \\
\text { yang berhubungan pada } \\
\text { pekerjaan }\end{array}$ & 180 & 93 & 51,66 & $\begin{array}{l}\text { Tidak } \\
\text { Baik }\end{array}$ \\
\hline 10 & $\begin{array}{l}\text { Pelatihan dapat mengolah } \\
\text { daya pikir untuk berpartisipasi } \\
\text { dalam meningkatkan atau } \\
\text { mengejar target perusahaan. }\end{array}$ & 180 & 120 & 66,66 & $\begin{array}{l}\text { Cukup } \\
\text { Baik }\end{array}$ \\
\hline & Rata-Rata & 180 & 118,1 & 65,55 & $\begin{array}{l}\text { Cukup } \\
\text { Baik }\end{array}$ \\
\hline
\end{tabular}

Sumber :Datadiolah (2019) 
Berdasarkan tabel diatas dapat dijelaskan bahwa nilai rata-rata jawaban responden atas seluruh item pertanyaan tentang variabel Pelatihan Kerja yang diukur melalui indikator:Tujuan, Sasaran, Pelatih, Materi, Metode, Pesertaadalah sebesar 118,1 atau setara dengan 65,55\% dengan kriteria " Cukup baik". Hal ini menggambarkan bahwa secara umum responden memberikan penilaian yang cukup baik terhadap Pelatihan Kerja di PT.Bank BRI Persero Kalianda.

Dari 10 indikator pertanyaan pelatihan kerja terdapt jawaban baik tentang instruktur yang berkwalitas dengan presentase $80,00 \%$. Jawaban cukup baik tentang materi yang disampaikan tentang materi yang disampaikan dengan presentase $67,77 \%$ dan jawaban tidak baik tentang pelatihan membangkitkan rasa ingin tahu dengan presentase 51,66\%.

\section{Analisis Variabel Terhadap Kinerja Karyawan}

(Y)

Dari hasil perhitungan interval kelas dan skor ratarata tersebut dapat disusun tabel distribusi frekuensi berdasarkan sebaran skor responden sebagai berikut :

\section{Tabel 4.11}

Distribusi Frekuensi Skor Kinerja Karyawan Berdasarkan Pernyataan Responden

\begin{tabular}{|c|c|l|c|c|}
\hline No & Interval & \multicolumn{1}{|c|}{ Kategori } & Frekuensi & Persentasi \% \\
\hline 1 & $42-50$ & Sangat Baik & 2 & 5,55 \\
\hline 2 & $34-41$ & Baik & 20 & 55,55 \\
\hline 3 & $26-33$ & Cukup Baik & 12 & 33,33 \\
\hline 4 & $18-25$ & Tidak Baik & 2 & 5,55 \\
\hline 5 & $10-17$ & Sangat Tidak Baik & 0 & 0 \\
\hline & & Jumlah & $\mathbf{3 6}$ & $\mathbf{1 0 0}$ \\
\hline
\end{tabular}

Sumber :Datadiolah (2019)

Berdasarkan data tabel 4.19 di atas, dari 36 orang responden penelitian yang menyatakan bahwa variabel Disiplin Kerjadi PT.Bank BRI Persero Kalianda "sangat baik" sebanyak 2 orang atau sekitar $6 \%$, yang menyatakan "baik" sebanyak 20 orang atau sekitar 55\%, yang menyatakan "cukup baik" sebanyak 12 orang atau sekitar 33\%, kemudian yang menyatakan "tidak baik" sebanyak 2 orang atau sekitar 6\%, dan "sangat tidak baik" tidak ada.

Dari hasil tersebut banyak didomonasi nilai baik dari kinerja karyawan yang sudah baik dengan presentase $55,55 \%$.

Berdasarkan hasil jawaban responden atas kuisioner variabel Kinerja Karyawanpada karyawan PT.Bank BRI Persero Kaliandadiperoleh hasil peresentase dan kriteria jawaban sebagai berikut:
Tabel 4.12 Hasil Penelitian Berdasarkan Indikator Kinerja Karyawan(Y)

\begin{tabular}{|c|c|c|c|c|c|}
\hline No & Indikator & $\begin{array}{l}\text { Skor } \\
\text { Max }\end{array}$ & $\begin{array}{c}\text { Skor } \\
\text { Riil } \\
\end{array}$ & $\begin{array}{c}\text { Persentase } \\
(\%)\end{array}$ & Kriteria \\
\hline 1 & $\begin{array}{l}\text { Saya selalu hati-hati dalam } \\
\text { melakukan pekerjaan }\end{array}$ & 180 & 150 & 83,33 & Baik \\
\hline 2 & $\begin{array}{l}\text { Saya merasa mampu bekerja } \\
\text { sesuai keinginan perusahan }\end{array}$ & 180 & 146 & 81,11 & Baik \\
\hline 3 & $\begin{array}{l}\text { Saya selalu melaksanakan tugas } \\
\text { dari perusahaan dengan benar }\end{array}$ & 180 & 118 & 65,55 & $\begin{array}{l}\text { Cukup } \\
\text { Baik }\end{array}$ \\
\hline 4 & $\begin{array}{l}\text { Saya sanggup melaksanakan tugas } \\
\text { tambahan apabila ditugaskan oleh } \\
\text { perusahaan }\end{array}$ & 180 & 138 & $\begin{array}{l}P \\
76,66\end{array}$ & Baik \\
\hline 5 & $\begin{array}{l}\text { Saya dapat menyelesaikan } \\
\text { pekerjaan dengan tepat waktu }\end{array}$ & 180 & 115 & 63,88 & $\begin{array}{l}\text { Cukup } \\
\text { Baik }\end{array}$ \\
\hline 6 & $\begin{array}{l}\text { Saya selalu bertanggung jawab } \\
\text { terhadap apa yang saya sedang } \\
\text { kerjakan }\end{array}$ & 180 & 135 & 75,00 & Baik \\
\hline 7 & $\begin{array}{l}\text { Saya mampu berkomunikasi } \\
\text { dengan baik dengan sesama } \\
\text { karyawan }\end{array}$ & 180 & 91 & 50,55 & $\begin{array}{l}\text { Tidak } \\
\text { Baik }\end{array}$ \\
\hline 8 & $\begin{array}{l}\text { Saya selalu mengikuti peraturan } \\
\text { yang ada }\end{array}$ & 180 & 144 & 80,00 & Baik \\
\hline 9 & $\begin{array}{l}\text { Saya mampu menciptakan } \\
\text { peluang dalam setiap } \\
\text { permasalahan pekerjaan }\end{array}$ & 180 & 92 & 51,11 & $\begin{array}{l}\text { Tidak } \\
\text { Baik }\end{array}$ \\
\hline \multirow[t]{2}{*}{10} & $\begin{array}{l}\text { Keterampilan saya mampu } \\
\text { mepercepat proses penyelesaian } \\
\text { pekerjaan }\end{array}$ & 180 & 142 & 78,88 & Baik \\
\hline & Rata-Rata & 180 & 127,1 & 70,61 & Baik \\
\hline
\end{tabular}

Data diolah (2019)

Berdasarkan tabel diatas dapat dijelaskan bahwa nilai rata-rata jawaban responden atas seluruh item pertanyaan tentang variabel Kinerja Karyawan yang diukur melalui indikator:Kualitas kerja SDM, Kuantitas kerja SDM, Tanggung Jawab, Kerja Sama, Ini adalah sebesar 127,1 atau setara dengan 70,61\% dengan kriteria "baik". Hal ini menggambarkan bahwa secara umum responden memberikan penilaian yang baik terhadap Kinerja Karyawan di PT.Bank BRI Persero Kalianda.

Dari 10 indikator pertanyaan kinerja karyawan terdapat jawaban baik tentang berhati-hati dalam pekerjaan dengan presentase $83,33 \%$. Jawaban cukup baik tentang menyelesaikan pekerjaan tepat waktu dengan presentase $63,88 \%$ dan jawaban tidak baik tentang menciptakan peluang dalam permasalahan perusahaan dengan presentase $51,11 \%$.

\section{KESIMPULAN}

Berdasarkan kajian teoritik dan hasil analisis data, maka dapat disimpulkan bahwa Disiplin Kerja, Motivasi Kerja dan Pelatihan Kerja berpengaruh positif terhadap Pelatihan Kerja. Kesimpulan tersebut 
ditunjukkan dari temuan-temuan hasil analisis sebagai berikut :

1. Bedasarkan hasil uji $t$ hipotesis variabelin dependen (Disiplin Kerja) pada PT. Bank Rakyat Indonesia (Persero) mempunyai pengaruh positif dan signifikan terhadap variable dependen (Kinerja Karyawan), dengan demikian Ho ditolak dan Ha diterima.

2. Bedasarkan hasil uji $t$ hipotesis variable independen (Motivasi Kerja) pada PT. Bank Rakyat Indonesia (Persero) mempunyai pengaruh positif dan signifikan terhadap variable dependen (Kinerja Karyawan), dengan demikian Ho ditolak dan Ha diterima.

3. Bedasarkan hasil uji $t$ hipotesis variable independen (Pelatihan Kerja) pada PT. Bank Rakyat Indonesia (Persero) berpengaruh positif terhadap variable dependen (Kinerja Karyawan), dengan demikian Ho diterima dan Ha ditolak.

4. Bedasarkan hasi uji f hipotesis variable Disiplin Kerja (X1), Motivasi Kerja (X2) dan Pelatihan Kerja (X3) pada PT. Bank Rakyat Indonesia (Persero) secara simultan mempunyai pengaruh positif terhadap variable Kinerja Karyawan(Y).

\section{SARAN}

Berdasarkan hasil analisa data secara kualitatif dan kuantitatif terdapat beberapa hal yang perlu direkomendasikan kepada PT. Bank BRI Persero Kalianda dalam rangka peningkatan Kinerja Karyawan agar lebih Setuju dari keadaan saat ini antara lain:

1. Pada Indikator Disiplin Kerja terdapat item pertanyaan rendah yaitu nomor tujuh tentang merapihkan peralatan setelah pekerjan selesai dengan presentase $51,66 \%$. Sehingga dapat ditarik kesimpulan bahwa karyawan di PT. Bank BRI Persero Kalianda harus mempunyai kesadaran diri untuk lebih rajin dalam merapikan peralatan kerja setelah bekerja supaya tertata rapi dan tidak ada yang hilang.

2. Pada Indikator Motivasi Kerja terdapat item pertanyaan rendah yaitu nomor satu dan nomor tujuh tantang penghasilan yang diterima dengan presentase $51,66 \%$ dan jabatan yang diterima dengan presentase $57,77 \%$. Sehingga dapat ditarik kesimpulan bahwa bagi pihak perusahaan di PT. Bank BRI Persero Kalianda harus mengikuti secara update standar minimum upah regional yang ada di daerah kalianda sehingga karyawan tidak peotes dan mengetahui standar minimum upah regional yang diterima, kemudian meningkatkan kualitas kerja menurut peneliti juga perlu sebagai bahan pertimbangan perusahaan dalam melakukan penilaian untuk memberikan dan menaikan jabatan pada karyawan.
3. Indikator Pelatihan Kerja terdapat item pertanyaan rendah yaitu nomor enam dan sembilan tentang pelatihan pengembangan potensi dengan persentase $53,33 \%$ dan tentang pelatihan membangkitkan rasa ingin tahu dengan persentase $51,66 \%$. Sehingga dapat ditarik kesimpulan bahwa pihak perusahaan PT. Bank BRI Persero Kalianda harus memberikan pelatihan yang sesuai untuk masing-masing setiap bidang pekerjaan, adakan kegiatan yang berhubungan dengan mengadakan Workshop yang menarik atau Camp berbasis pelatihan karakter tenaga kerja.

4. Pada indikator Kinerja Karyawan terdapat item pertanyaan rendah yaitu nomor tiga empat tujuh dan sembilan. Sehingga dapat ditarik kesimpulan bahwa karyawan di PT. Bank BRI Persero Kalianda harus lebih mampu berkomunikasi dengan baik dengan sesama karyawan dan harus mampu menyelesaikan setiap permasalahan pekerjaan.

\section{DAFTAR PUSTAKA}

Anwar Prabu Mangkunegara.2013. Manajemen Sumber Daya Manusia

Perusahaan.Bandung:PT.Remaja Rosdakarya

Anwar Prabu Mangkunegara 2007. Manajemen

Sumber Daya Manusia Perusahaan. PT. Remaja Rosdakarya, Bandung.

Bejo Siswanto, 2005. Manajemen Tenaga Kerja Indonesia Pendekatan Administratif dan Operasional, Jakarta, Bumi Aksara.

Budi, Triton P. 2010. Manajemen Sumber Daya Manusia: Perspektif Partnership dan Kolektif. Jogjakarta: Oryza.

Dessler Gary 2005. Manajemen Sumber Daya Manusia. Alih bahasa: Eli Tanya. Penyunting Bahasa: Budi Supriyanto. Jakarta: Indeks.

Dessler, 2010. Pengertian Pelatihan kerja. Jakarta.

Fajar, 2013. Evaluasi Pelatihan Kerja. UGM, Yogyakarta,

Ghozali, Imam, 2013. Aplikasi Analisis Multivariate Dengan Program SPSS, Edisi Keempat, Penerbit Universitas Diponegoro.

Gibson 2008. Manajemen Sumber Daya Manusia. Jakarta : Raja Grafindo Persada. 
Handoko T. Hani 2013, Manajemen Personalia dan Sumber Daya Manusia. Edisi 2. BPFE Yogyakarta.

Hasibuan Malayu S.P 2011, Manajemen Sumber Daya Manusia, Edisi Revisi, Bumi Aksara, Jakarta.

Hasibuan, 2005. Instruktur Pelatihan Kerja, Bumi Aksara, Jakarta.

Herzberg 2008. Manajemen Sumber Daya Manusia. Jakarta : PT. Bumi Aksara.

Mathis dan Jackson 2009. Manajemen Sumber Daya Manusia. Perusahaan. PT. Remaja Rosdakarya, Bandung.

Mangkuprawira 2007. Manajemen Sumber Daya Manusia. PT. Rineka Cipta, Jakarta.

Mondy, 2008. Pengertian pelatihan kerja. Bumi Angkasa, Jakarta.

Narmodo dan Farid 2010. Manajemen Sumber Daya Manusia. Edisi Pertama. Cetakan Pertama. Yogyakarta: BPFE.

Ridwan 2007, Rumus dan data dalam analisis statistika, Bandung : Alfabeta

Rivai dan Basri 2005. Manajemen Sumber Daya Manusia Untuk Perusahaan. Cetakan Pertama. PT. Raja Grafindo. Jakarta.

Rivai, Veithzal 2014. Manajemen Sumber Daya Manusia Untuk Perusahaan. Cetakan Pertama. PT. Raja Grafindo.

Robbins, Stephen P. (2006). Perilaku Organisasi. Edisi kesepuluh. Jakarta: PT Indeks Kelompok Gramedia

Saydam dalam Kadarisman 2012. Pengaruh Motivasi, Terhadap Kinerja Pegawai Pada Dinas Perhubungan Dan Telekomunikasi Provinsi Jawa Tengah.

Siagian, 2007. Manajemen Sumber Daya Manusia. PT Bumi Aksara: Jakarta

Simamora, Henry, 2004, Manajemen Sumber Daya Manusia, Edisi Ketiga, Cetakan Pertama, Bagian Penerbitan STIE YKPN, Yogyakarta.

Simamora, 1999. Tujuan pelatihan kerja, Yogyakarta.
Siregar, Sofian. 2015. Statistik Parametik Untuk Penelitian Kuantitatif Dilengkapi Dengan Perhitungan Manual dan Aplikasi SPSS Versi 17. Jakarta: PT. Bumi Askara

Sofyandi Herman, 2008. Manajemen Sumber Daya Manusia, Edisi Pertama, Penerbit Graha Ilmu, Yogyakarta.

Sugiono, 2009. Metode Penelitian Bisnis (Pendekatan Kuantitatif, Kualitatif, dan R\&D). Bandung: Alfabeta.

Sugiono, 2013. Metode Penelitian Kuantitatif, Kualitatif dan $R \& D$. Bandung: Alfabeta

Sugiyono, 2006 Statistika Untuk Penelitian. Cetakan Ketujuh. Bandung: CV. Alfabeta.

Sugiyono, 2008. Metodologi penelitian manajemen Bandung: CV. Alfabeta

Sulistiyani dan Rosidah, 2009. Manajemen Sumber Daya Manusia. Raja Grafindo Persada.

Wahdjosumidjo, 1992. Pengertian motivasi kinerja karyawan. Bumi Angkasa, Jakarta.

Wirawan, 2009. Manajemen Sumber Daya Manusia Untuk Perusahaan. Cetakan Pertama, Raja Grafindo. Jakarta.

Yuli, 2005. Manajemen Sumber Daya Manusia. Raja Grafindo Persada. Jakarta. 